\title{
ADHESIVE PROPERTIES OF ESCHERICHIA COLI FROM URINARY-TRACT INFECTIONS
}

\author{
Sarah A. Varian and E. Mary Cooke \\ Department of Microbiology, University of Leeds, \\ Leeds LS2 $9 \mathrm{NL}$
}

Plates III-IV

THE ABILITY of bacteria to adhere to epithelial surfaces has been correlated with their pathogenicity. The bacteria studied include enteropathogenic Escherichia coli in the gut of man (McNeish et al., 1975) and of animals (Sellwood et al., 1975; Nagy, Moon and Isaacson, 1977), streptococci in the human oral cavity (Ellen and Gibbons, 1974), gonococci in the urogenital tract (Ward and Watt, 1975), Vibrio cholerae in the small intestine (Freter and Jones, 1976; Jones, Abrahams and Freter, 1976) and mycoplasmas in the respiratory tract (Powell et al., 1976).

The adhesion between bacteria and epithelial surfaces may be specific and selective, involving bacterial cell-surface components and specific surface components of the host mucosal cells. For example, pathogenic strains of E. coli adhere to the ileum rather than the duodenum of pigs and calves, and within the ileum adhere to the tips rather than the bases of the villi (Arbuckle, 1970; Smith, 1977). However, the surface components of bacteria and of host cells responsible for this adhesion have not been fully defined. The bacterial surface components may be fimbriae. These are non-flagellar filamentous appendages, the term "fimbriae" being introduced by Duguid and co-workers (1955) who described the haemagglutinating ability of fimbriate bacteria. Other factors in addition to fimbriae may also be involved or the mechanism of adhesion may depend upon factors that do not include fimbriae.

Studies on adhesion of $E$. coli to epithelial surfaces have included observations on adhesion to and penetration of monolayers of cultured HeLa and Hep 2 cells (Du Pont et al., 1971), guinea-pig eyes (Serény, 1957; Du Pont et al., 1971; Guerrant et al., 1975), adhesion studies with epithelial cells from the urinary tract (Svanborg Edén et al., 1976) and with epithelial cells from the buccal cavity (Ellen and Gibbons, 1974).

The aim of our investigation was to compare the ability of strains of E. coli to adhere to and to invade a variety of cell surfaces, and to compare the adhesive properties of strains of $E$. coli from urinary-tract infections and from normal faeces, to determine whether there is a correlation between the source of a strain and its adhesive and invasive properties. 


\section{MATERIALS AND METHODS}

\section{Source and identification of strains}

Fifty strains of $E$. coli were obtained from specimens from the diagnostic laboratory. All were from female patients, aged 15-50, whose urine contained more than $10^{5}$ organisms $/ \mathrm{ml}$. There was no clinical evidence to suggest upper-tract involvement, but localisation studies were not performed. In addition, 20 strains were obtained from urinary-tract infections in which there appeared to be upper-tract involvement. Ten strains obtained by ureteric catheterisation were kindly provided by Professor F. O'Grady and 10 strains were from hospital patients considered clinically to be suffering from pyelonephritis of whom eight had radiological evidence of renal damage and the remaining two had capillary erythrocyte sedimentation rates of $25 \mathrm{~mm} \mathrm{Hg}$ or more.

Faecal strains were obtained from 20 healthy people who had neither been in hospital nor received any antibacterial drugs during the previous year.

Organisms were identified as $E$. coli as described by Cooke (1968).

With the exception of strains from upper-tract infection, provided by Professor F. O'Grady, strains were kept for periods not exceeding 2 years. They were stored on Dorset egg slopes at room temperature or, towards the end of the investigation, in liquid nitrogen. No strains were serially subcultured and strains from all sources were handled in the same way.

\section{Adhesion tests}

HeLa-cell monolayers. The method was based on that of LaBrec et al. (1964), with the following modifications: HeLa Ohio cells were maintained in tissue-culture bottles as monolayers in Minimal Essential Medium (Glasgow's modification of Eagle's medium). Immediately before use, each $150 \mathrm{ml}$ of this medium was supplemented with tryptose phosphate broth 20 $\mathrm{ml}$, calf serum $20 \mathrm{ml}$, glutamine solution (containing glutamine $29.2 \mathrm{mg} / \mathrm{ml}$ ) $2 \mathrm{ml}$, and $3 \%$ sodium bicarbonate $10 \mathrm{ml}$. The stripping medium was $100 \mathrm{ml}$ of phosphate-buffered saline (PBS), $p \mathrm{H} \mathrm{7.3,} \mathrm{to} \mathrm{which} \mathrm{were} \mathrm{added} 1 \%$ versene $2 \mathrm{ml}, 10 \%$ trypsin $0.5 \mathrm{ml}$, and $3 \%$ sodium bicarbonate $3.5 \mathrm{ml}$ immediately before use; the composition of the PBS was $\mathrm{NaCl} 8.0 \mathrm{~g} /$ litre, $\mathrm{K}_{2} \mathrm{HPO}_{4}$ $1.21 \mathrm{~g} /$ litre, $\mathrm{KH}_{2} \mathrm{PO}_{4} 0.34 \mathrm{~g} /$ litre.

Infection of cells on coverslips was by the method of LaBrec et al. (1964). Samples were taken at 3, 5, 7 and $18 \mathrm{~h}$. The coverslip preparations were washed in two changes of saline, fixed in a 3:1 mixture of methanol and acetic acid, and stained with Giemsa at $p \mathrm{H} 7.0$ before being examined by direct light microscopy.

Adhesive strains attached to the monolayers within $3 \mathrm{~h}$ (fig. 1). Invasion occurred within $7 \mathrm{~h}$ with some disruption of the monolayer (fig. 2). After $18 \mathrm{~h}$, destruction of the monolayer by invasive strains was almost complete (fig. 3).

A strain was deemed to be non-adhesive and non-invasive if, after $7 \mathrm{~h}$, no difference in appearance was observed between infected monolayers and uninfected controls.

Urinary epithelial cells. The method was that of Svanborg Edén et al. (1976). A control of epithelial cells $10^{5} / \mathrm{ml}$ of PBS but with no bacteria was included in each test run. Each bacterial strain was tested twice, on different days.

After incubation of the bacteria with the uro-epithelial cells and washing of the cells to remove unattached organisms, the cells were examined by direct light microscopy. The number of bacteria adhering to whole viable epithelial cells was counted. Cells that were damaged, clumped or stained by trypan blue were not included. The number of bacteria adhering to 50 epithelial cells was counted.

Strains with an average of more than 10 bacteria per epithelial cell were classed as adhesive (fig. 4) and those with between one and 10 poorly adhesive. Some strains showed no bacterial attachment to the cells and were classed as non-adhesive.

Buccal-cavity epithelial cells. The method used was a modification of that of Gibbons and van Houte (1971). Epithelial cells were collected as described by them and washed free from unattached bacteria by repeated centrifugation; $10^{8}$ bacteria and $10^{5}$ epithelial cells were mixed by rotation at $37^{\circ} \mathrm{C}$ for $1 \mathrm{~h}$. The epithelial cells were again washed free from unattached bacteria 
by repeated centrifugation, and examined and counted as described for urinary epithelial cells.

Difficulty was sometimes experienced in separating the bacteria attached to the epithelial cells at the time of their collection from the epithelial cells. This background count could be reduced by washing the unattached bacteria through Millipore membrane filters of pore size 14 $\mu \mathrm{m}$ (Gibbons and van Houte, 1977) but this treatment increased the number of strains taking up the trypan-blue dye and, therefore, the centrifugation method was used.

A control was included in each set of tests, to determine the number of bacteria attached to the cells at the time of their collection. Adherence was expressed as the number of bacteria bound per epithelial cell minus the average background count for that particular sample of buccal epithelial cells.

Adhesion to and invasion of guinea-pig eyes. A loopful of an overnight bacterial culture grown on nutrient agar was inoculated into the conjunctival sac of a guinea-pig (Serény, 1957). The eyelid was held closed for one minute. Animals were examined during a period of 4 days for evidence of keratoconjunctivitis. They were then killed and the eyes were removed and examined histologically.

\section{Fimbrial haemagglutination}

Type-1 fimbriae were tested for at $4^{\circ} \mathrm{C}$ by the method of Duguid et al. (1955), inhibition of haemagglutination in the presence of D-mannose being taken to indicate the presence of type-1 fimbriae.

\section{RESULTS}

\section{Adhesion to HeLa-cell monolayers}

The results are given in tables I and II.

A significant difference $(p<0.05)$ was found in the abilities of urinary and faecal $E$. coli strains to adhere to the monolayers. No significant difference was found in the invasive properties of the strains tested, nor was there any significant difference in behaviour between the strains from the two types of urinary-tract infection.

If the adhesive and invasive properties are considered together, the significance of the results obtained increases $(p<0.01)$.

Between $3 \mathrm{~h}$ and $5 \mathrm{~h}$ it was sometimes difficult to identify whether a strain

TABLE I

Adhesion of Escherichia coli strains to different cell types

\begin{tabular}{|c|c|c|c|c|}
\hline \multirow[b]{2}{*}{ Source of strains } & \multirow[b]{2}{*}{$\begin{array}{l}\text { Number } \\
\text { tested }\end{array}$} & \multicolumn{3}{|c|}{$\begin{array}{l}\text { Number (and percentage) of test } \\
\text { strains showing adhesion to }\end{array}$} \\
\hline & & $\begin{array}{l}\text { urinary } \\
\text { epithelial } \\
\text { cells }\end{array}$ & $\begin{array}{l}\text { buccal } \\
\text { epithelial } \\
\text { cells }\end{array}$ & HeLa cells \\
\hline $\begin{array}{l}\text { Presumed lower } \\
\text { urinary-tract } \\
\text { infections (UTI) }\end{array}$ & 50 & $26(52)$ & $23(46)$ & $12(24)$ \\
\hline $\begin{array}{l}\text { UTI, upper-tract } \\
\text { involvement }\end{array}$ & 20 & $11(55)$ & $10(50)$ & $5(25)$ \\
\hline Faeces & 20 & $2(10)$ & $1(5)$ & $0(0)$ \\
\hline
\end{tabular}


TABLE II

Invasion of HeLa cell monolayers by E. coli strains

\begin{tabular}{lc|c}
\hline Source of strains & $\begin{array}{c}\text { Number } \\
\text { tested }\end{array}$ & $\begin{array}{c}\text { Number (and percentage) } \\
\text { of test strains } \\
\text { showing invasion }\end{array}$ \\
\hline $\begin{array}{l}\text { Presumed lower } \\
\text { urinary-tract }\end{array}$ & & \\
infections (UTI) & 50 & $9(18)$ \\
$\begin{array}{l}\text { UTI, upper-tract } \\
\text { involvement }\end{array}$ & 20 & $2(10)$ \\
Faeces & 20 & $1(5)$ \\
\hline
\end{tabular}

was adhering to or invading the monolayers before penetrating them. However, after $5 \mathrm{~h}$ there was disruption of the cell layer by penetrating strains but not by adhesive strains.

\section{Adhesion to urinary-tract epithelial cells}

The results are given in table I. Significantly more strains from urinarytract infections adhered to the epithelial cells than did strains from faeces $(p<0.001)$. No differences could be demonstrated between strains from lower urinary-tract infections and those from infections in which the upper tract was involved. The use of cells from the same individual on different days or pooled cells from several people did not affect the results. With preparations in which adhesion was observed, attachment of bacteria to the cells was uneven. Some cells had no bacteria attached, whilst others in the same field of view might have many adherent bacteria. Occasionally the epithelial cells were covered by so many bacteria that only a rough estimate of bacterial numbers could be made (fig. 5). Cells taking up the trypan-blue dye had significantly fewer $(p<0.001)$ attached bacteria than those not taking up the dye.

\section{Adhesion to buccal-cavity epithelial cells}

The results are given in table I. Strains from urinary-tract infections adhered in significantly greater numbers $(p<0.005)$ than strains from normal faeces. There was no significant difference between the strains from lower urinary-tract infections and those from infections involving the upper tract. As was observed with urinary-tract epithelial cells, attachment of bacteria to different epithelial cells was uneven. The use of cells from the same individual on different days or pooled cells from several people did not affect the results obtained, though the background count did vary.

\section{Adhesion and invasion of guinea-pig eyes}

No positive results were obtained when the eyes were examined either macro- or microscopically. 


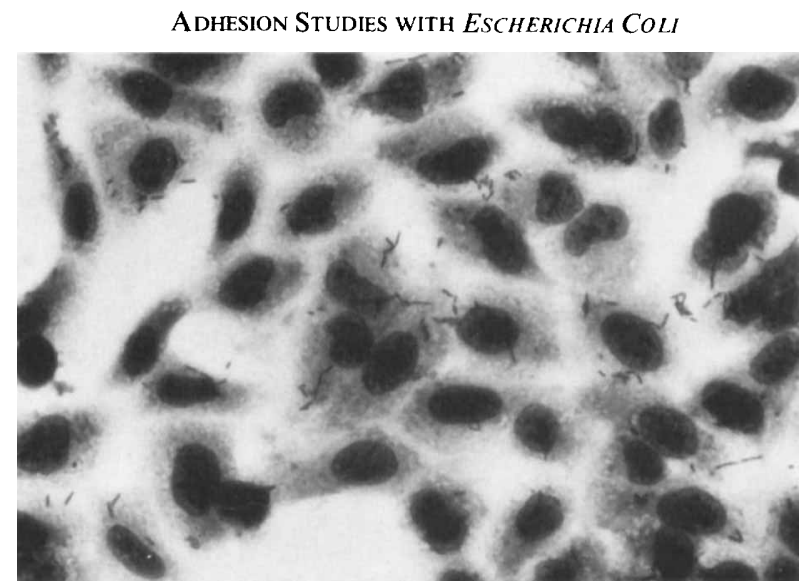

FIG. 1.-HeLa-cell monolayer $3 \mathrm{~h}$ after inoculation with a strain of Escherichia coli, showing adherent bacteria. Giemsa. $\times 310$.

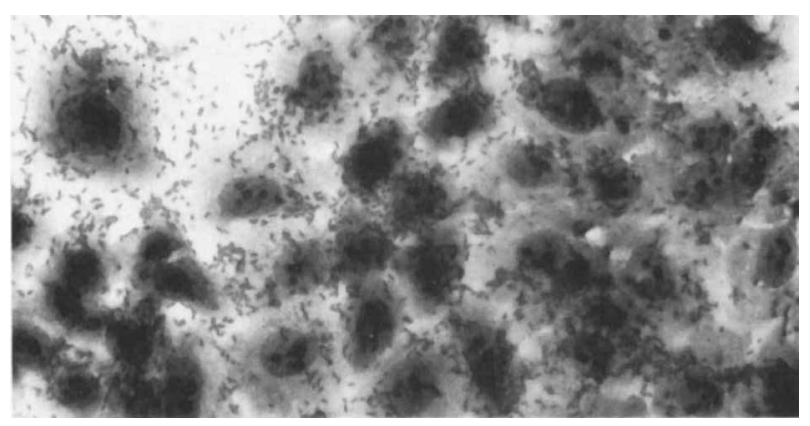

FIG. 2.-HeLa-cell monolayer $7 \mathrm{~h}$ after inoculation, showing some disruption of the monolayer. Giemsa. $\times 200$.

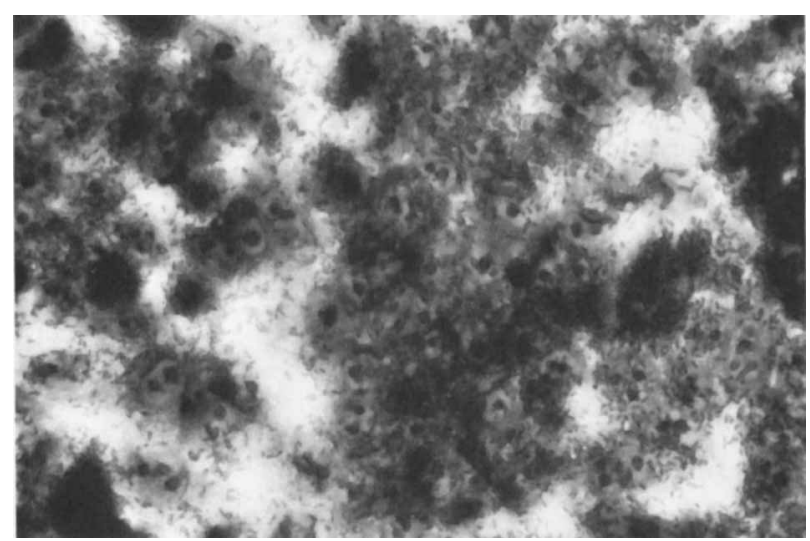

FIG. 3.-HeLa-cell monolayer $18 \mathrm{~h}$ after inoculation, showing destruction of monolayer. Giemsa. $\times 200$. 
AdHesion Studies WITH ESCHERICHIA COLI

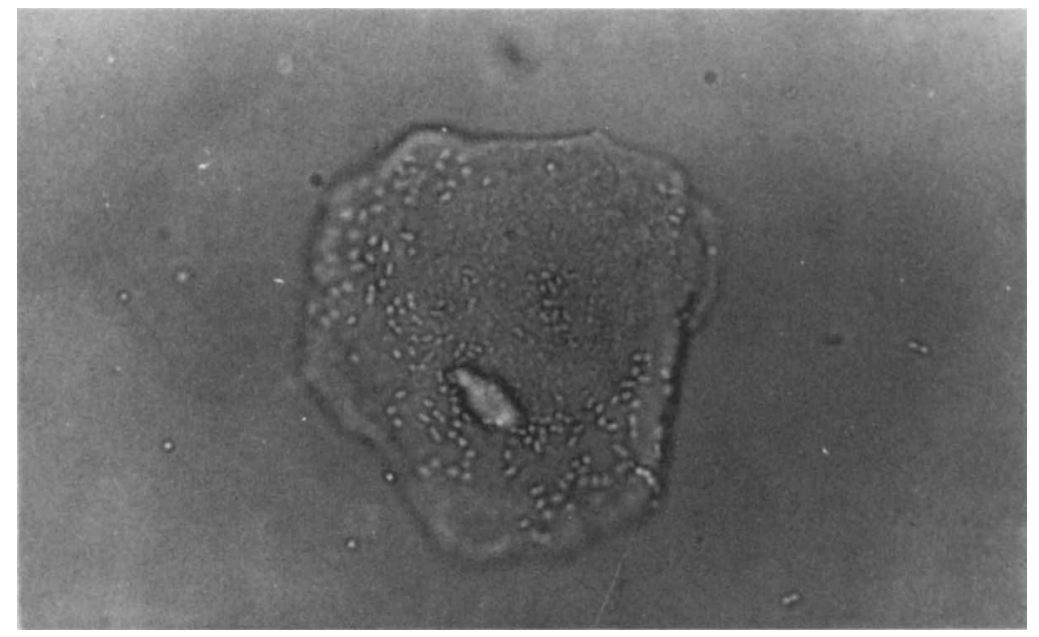

FIG. 4.-Urinary-tract epithelial cell with attached bacteria. Unstained. $\times 1000$.

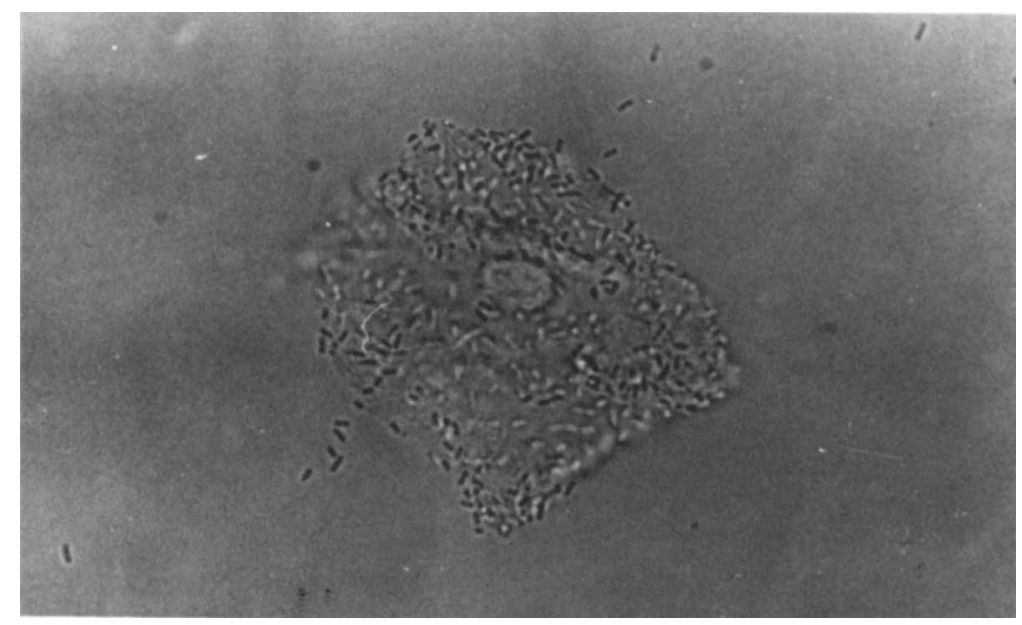

FIG. 5.-Urinary-tract epithelial cell covered with numerous bacilli. Unstained. $\times 1000$. 
TABLE III

E. coli strains possessing type-1 fimbriae

\begin{tabular}{lc|c}
\hline Source of strains & $\begin{array}{c}\text { Number } \\
\text { tested }\end{array}$ & $\begin{array}{c}\text { Number (and percentage) } \\
\text { of type-1 fimbriate strains }\end{array}$ \\
\hline $\begin{array}{l}\text { Presumed lower } \\
\text { urinary tract } \\
\text { infections (UTI) }\end{array}$ & 50 & $28(56)$ \\
$\begin{array}{l}\text { UTI, upper tract } \\
\text { involvement }\end{array}$ & 20 & $11(55)$ \\
Faeces & 20 & $11(55)$ \\
\hline
\end{tabular}

\section{Fimbrial haemagglutination}

The results are given in table III. All strains that adhered in numbers of 10 or more per epithelial cell could be shown to produce fimbriae. However, many non-adhesive and non-invasive strains also produced fimbriae (table IV).

\section{Ability to adhere to different types of cell}

The results are given in tables I, IV and V. In general, strains that adhered to the HeLa-cell monolayers adhered to both types of epithelial cell. However, some epithelium-adhering strains, often those that were poorly adhesive, did not adhere to the HeLa monolayers. Invasive strains adhered to the epithelial cells. Strains that adhered in numbers of 10 or more bacteria per urinary epithelial cell generally adhered to buccal epithelial cells, but strains that were poor or non-adhering in tests with urinary epithelial cells did not adhere, or adhered poorly, to cells from the buccal cavity. On average the number of cells of a given strain adhering to buccal cells was $20-40 \%$ fewer than when the test was done with urinary epithelial cells (fig. 6).

In summary, the bacteria attached best to the urinary epithelial cells, less well to the buccal epithelial cells and least to the HeLa cells.

TABLE IV

Patterns of adhesion and invasion of E. coli strains

\begin{tabular}{cccccc}
\hline & & \multicolumn{3}{c}{ Adhesion to } & \\
\cline { 3 - 5 } Pattern & Fimbriation & $\begin{array}{c}\text { urinary- } \\
\text { tract } \\
\text { epithelial } \\
\text { cells }\end{array}$ & $\begin{array}{c}\text { buccal } \\
\text { epithelial } \\
\text { cells }\end{array}$ & $\begin{array}{c}\text { HeLa } \\
\text { cells }\end{array}$ & $\begin{array}{c}\text { Invasion of } \\
\text { HeLa cells }\end{array}$ \\
\hline I & + & ++ & ++ & + & + \\
II & + & ++ & ++ & + & - \\
III & + & ++ & ++ & - & - \\
IV & + & ++ & - & - & - \\
V & + & - & - & - & - \\
VI & - & - & - & - & - \\
\hline
\end{tabular}




\section{TABLE V}

Relationship of the source of the test strains to patterns of adhesive and invasive behaviour

\begin{tabular}{l|ccc}
\hline & \multicolumn{3}{|c}{$\begin{array}{c}\text { Number (and percentage) } \\
\text { of strains derived from }\end{array}$} \\
\cline { 2 - 3 } Pattern* & $\begin{array}{c}\text { presumed lower } \\
\text { urinary tract } \\
\text { infection (UTI) }\end{array}$ & $\begin{array}{c}\text { UTI with } \\
\text { upper tract } \\
\text { involvement }\end{array}$ & faeces \\
\hline I & $9(18)$ & $2(10)$ & $1(5)$ \\
II & $12(24)$ & $5(25)$ & $0(0)$ \\
III & $2(4)$ & $3(15)$ & $0(0)$ \\
IV & $3(6)$ & $1(5)$ & $1(5)$ \\
V & $2(4)$ & $0(0)$ & $9(45)$ \\
VI & $22(44)$ & $9(45)$ & $9(45)$ \\
\hline
\end{tabular}

* see table IV
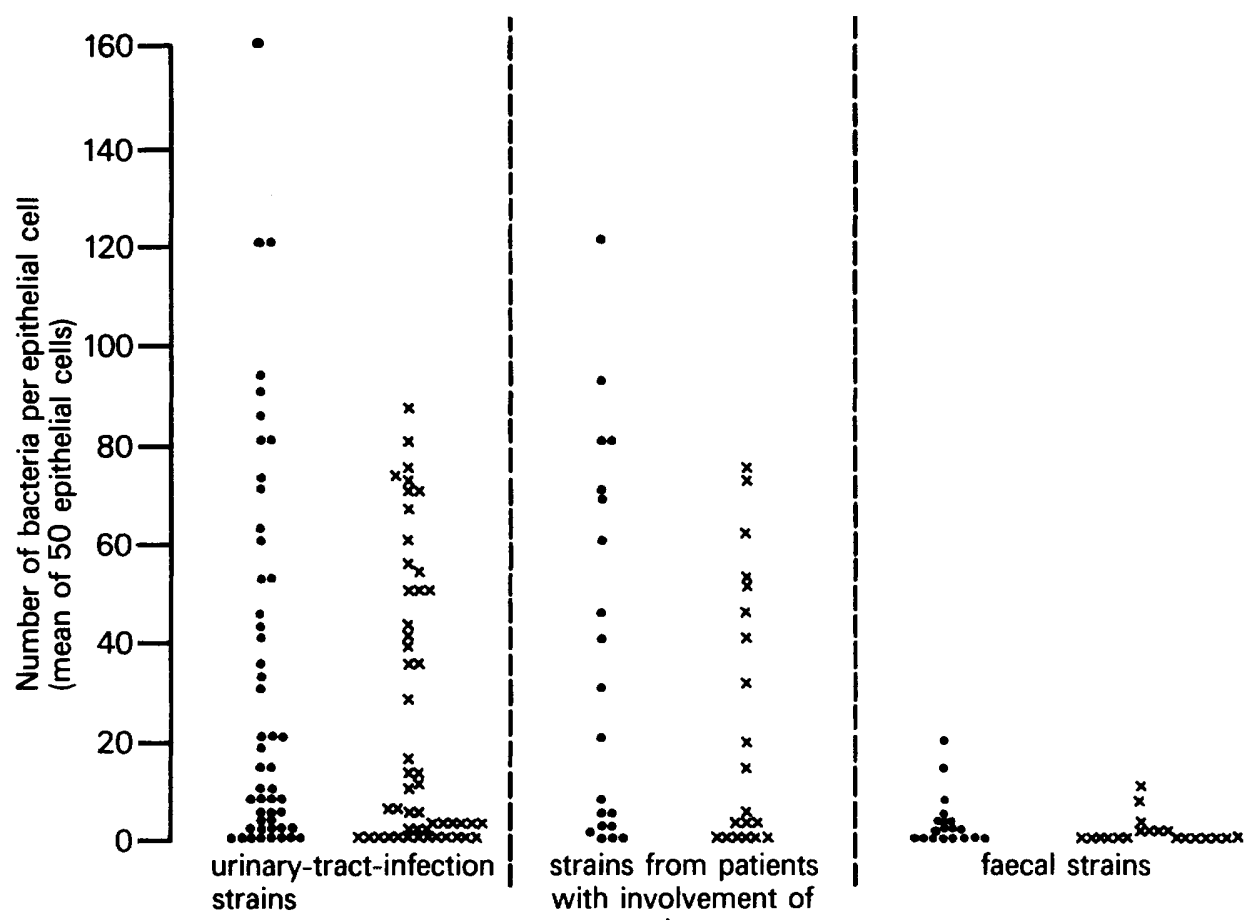
with involvement of faecal strains upper urinary tract

Fig. 6.-Adherence of strains of Escherichia coli to urinary-tract epithelial cells $(\bullet)$ and to buccal epithelial cells $(x)$. 


\section{Discussion}

The in-vitro methods used here to test for adhesion of $E$. coli were designed to be used in relation to particular types of infection.

The uroepithelial-cell adhesion test has several factors in common with conditions known to exist in the bladder during infection (Svanborg Edén, Eriksson and Hanson, 1977) and it provides a simple method of studying bacterial adhesion in relation to urinary-tract infections. The use of trypan blue as an indicator of cell viability is not entirely satisfactory (King et al., 1959) but it does give some indication of the state of the cells.

The buccal-cell test was based on a technique originally used to study adhesion of streptococcal species (Ellen and Gibbons, 1974; Gibbons and van Houte, 1975). The HeLa-cell monolayer and guinea-pig eye tests have been used to study strains isolated from the gut. Work by LaBrec et al. (1964) has shown that the ability of organisms to attach to and penetrate the monolayers and cornea reflects the enteroinvasive properties of those strains.

Svanborg Edén et al. (1976) demonstrated a significant difference between the ability of strains from patients with acute symptomatic pyelonephritis or cystitis and those from asymptomatic bacteriuria to attach to normal human urinary-tract epithelial cells. We have shown a difference between the adhesive properties of strains from urinary-tract infections and those from faeces. This is of interest because the faeces are the source of the majority of strains causing urinary-tract infections. In addition, we have shown that these adhesive strains also adhere, though not as well, to at least two other types of cell.

This capacity to adhere could facilitate the ascent of strains causing urinary-tract infections to the bladder and their establishment there by resisting the flushing action of urine. If, in addition, the bacteria could invade and multiply within the cells lining the bladder and urinary tract, this could further enhance their virulence. However, many E. coli strains not possessing these properties are able to survive in the urinary tract to cause infection, the development of urinary-tract infection being related not only to the nature of the invading organism but also to the host's defences.

Our results indicate that adhesion to urinary-tract epithelial cells is the most suitable of the systems used for the study of strains from urinary-tract infections. There are several possible explanations for the reduction in numbers of bacteria adhering to buccal as compared to urinary epithelial cells. One possibility to be considered is that there are smaller numbers of attachment sites per buccal cell, though analysis of the results does not support this. Another is that the flora already attached to these cells interferes in some way, physically or biochemically, with the adherence of the $E$. coli. A third possibility is that specific factors on the surfaces of the epithelial cells are involved, as well as factors on the bacterial cell surfaces.

Previous workers (LaBrec et al., 1964; DuPont et al., 1971) have found that if bacteria adhere to and penetrate HeLa-cell monolayers, they are also positive in the guinea-pig eye test. Here again, the explanation for the results we obtained may be the specificity of the interaction between the bacteria and 
epithelial cells. The previous studies have concerned organisms from the gut.

The possible role of fimbriae in the attachment process remains obscure, and there is no evidence as to whether the uneven adherence observed is due to cells in different stages of their life cycle or perhaps reflects a heterogeneous population.

There has been considerable discussion concerning the pathogenicity of $E$. coli strains causing urinary-tract infections. They may be merely representative of faecal strains, or they may differ in that they may possess special properties that enhance their virulence. These characteristics include $\mathrm{O}$ serotype (Kunin and Halmagyi, 1962; Rantz and Alto, 1962; Vosti et al., 1964) haemolysin production (Dudgeon, Wordley and Bawtree, 1921; Vahlne, 1945); necrotoxin production (Sjöstedt, 1946); and production of large amounts of K antigens (Glynn, Brumfitt and Howard, 1971).

The present work provides evidence that there is another factor, adhesiveness, possessed more commonly by strains from urinary-tract infections than by those from faeces; this may contribute to the pathogenicity of these strains.

\section{SUMMARY}

Strains of Escherichia coli from upper and lower urinary-tract infections and from faeces were examined: for their ability to adhere to urinary-tract epithelial cells, buccal epithelial cells and HeLa cells; to invade HeLa cells; to cause keratoconjunctivitis in the guinea-pig eye (Serény test) and for the presence of type-I fimbriae. Strains from infections of the upper and lower urinary tract more commonly adhered and invaded than did faecal strains, but none of the strains gave a positive result in the Sereny test. Adhesive strains adhered best to urinary epithelial cells, less well to buccal epithelial cells and poorly to HeLa cells. All adhesive strains were fimbriate, but not all fimbriate strains adhered.

We are grateful to Professor F. O'Grady for providing strains of E. coli from upper urinary-tract infections, and we thank the staff of the Urology Department, Leeds General Infirmary, and the Diagnostic Laboratory, Microbiology Department, Leeds University, for their assistance in obtaining specimens. It is a pleasure to acknowledge our indebtedness to $\mathrm{Dr}$ Shirley Holt who carried out the histological examination of the guinea-pig eyes. S.A.V.holds a Medical Research Council Studentship.

\section{REFERENCES}

ArbucKle, J. B. R. 1970. The location of Escherichia coli in the pig intestine. J. med. Microbiol., 3, 333.

COOKE, E. M., 1968. Properties of strains of Escherichia coli isolated from the faeces of patients with ulcerative colitis, patients with acute diarrhoea and normal persons. J. Path. Bact., 95, 101.

Dudgeon, L. S., Wordley, E AND BAWTREe, F. 1921. On Bacillus coli infections of the urinary tract especially in relation to haemolytic organisms. J. Hyg., Camb., 20, 137.

Duguid, J. P., Smith, I. W., Dempster, G. ANd Edmund, P. N. 1955. Non-flagellar filamentous appendages ("Fimbriae") and haemagglutinating activity in Bacterium coli. J. Path. Bact., 70, 335. 
DuPont, H. L., Formal, S. B., Hornick, R. B., Snyder, M. J., Libonati, J. P., Sheahan, D. G., LaBrec, E. H. and Kalas, J. P. 1971. Pathogenesis of Escherichia coli diarrhea. New Eng. J. Med., 285, 1.

Ellen, R. P. AND GibBons, R. J. 1974. Parameters affecting the adherence and tissue tropisms of Streptococcus pyogenes. Infect. Immun., 9, 85 .

FRETER, R. AND JONES, G. W. 1976. Adhesive properties of Vibrio cholerae; nature of the interaction with intact mucosal surfaces. Infect. Immun., 14, 246.

GibBONS, R. J. AND VAN Houte, J. 1971. Selective bacterial adherence to oral epithelial surfaces and its role as an ecological determinant. Infect. Immun., 3, 567.

Gibbons, R. J. AND van Houte, J. 1975. Bacterial adherence in oral microbial ecology. Ann. Rev. Microbiol., 29, 19.

Glynn, A. A., Brumfitt, W. And Howard, C. J. 1971. K. antigens of Escherichia coli and renal involvement in urinary-tract infections. Lancet, $1,514$.

Guerrant, R. L., Moore, R. A., Kirschenfeld, P. M. and Sande, M. A. 1975. Role of toxigenic and invasive bacteria in acute diarrhea of childhood. New Eng. J. Med., 293, 567.

Jones, G. W., Abrams, G. D. AND Freter, R. 1976. Adhesive properties of Vibrio cholerae: adhesion to isolated rabbit brush border membranes and hemagglutinating activity. Infect. Immun., 14, 232.

King, D. W., Paulson, S. R., Puckett, N. L. and Krebs, A. T. 1959. Cell death IV. The effect of injury on the entrance of vital dye in Erlich tumor cells. Am. J. Path., 35, 1067.

Kunin, C. M. and Halmagyi, N. E. 1962. Urinary-tract infections in schoolchildren. II Characterization of invading organisms. New Eng. J. Med., 266, 1297.

LaBrec, E. H., Schneider, H., Magnani, T. J. and Formal, S. B. 1964. Epithelial cell penetration as an essential step in the pathogenesis of bacillary dysentery. J. Bact., 88, 1503.

MCNeish, A. S., Turner, P., Fleming, J. and Evans, N. 1975. Mucosal adherence of human enteropathogenic Escherichia coli. Lancet, 2, 946.

NAGY, B., Moon, H. W., IsaACSON, R. E. 1977. Colonization of porcine intestine by enterotoxigenic Escherichia coli: selection of piliated forms in vivo, adhesion of piliated forms to epithelial cells in vitro, and incidence of a pilus antigen among porcine enteropathogenic Escherichia coli. Infect. Immun., 16, 344.

Powell, D. A., Hu, P. C., Wilson, M., Collier, A. M. and Baseman, J. B. 1976. Attachment of Mycoplasma pneumoniae to respiratory epithelium. Infect. Immun., 13, 959.

RANTZ, L. A. 1962. Serological grouping of Escherichia coli. Study in urinary tract infection. Archs. int. Med., 109, 91.

Sellwood, R., Gibbons, R. A., Jones, G. W. ANd Rutter, J. M. 1975. Adhesion of enteropathogenic Escherichia coli to pig intestinal brush borders: the existence of two pig phenotypes. J. med. Microbiol., 8, 405.

SERÉNY, B., 1957. Experimental keratoconjunctivitis shigellosa. Acta microbiol. Hung., 4, 367.

Suöstedt, S., 1946. Pathogenicity of certain serological types of Escherichia coli. Acta path. microbiol. scand., suppl. 63.

SMITH. H. 1977. Microbial surfaces in relation to pathogenicity. Bact. Rev., 41, 475.

Svanborg EdÉn, C., Eriksson, B. ANd Hanson, L. A. 1977. Adhesion of Escherichia coli to human uroepithelial cells in vitro. Infect. Immun.,18, 767.

Svanborg Edén, C., Hanson, L. A., Jodal, U., Lindberg, U. and Sohl Akerlund, A. 1976. Variable adherence to normal human urinary tract epithelial cells of Escherichia coli strains associated with various forms of urinary tract infection. Lancet, 2, 490.

VAHLNE, G. 1945. Serological typing of the colon bacteria. Acta. path. microbiol. scand., suppl. 62 .

Vosti, K. L., Goldberg, L. M., Monto, A. S. and Rantz, L. A. 1964. Host-parasite interaction in patients with infections due to Escherichia coli. 1. The serotyping of E. coli from intestinal and nonintestinal sources. J. clin. Invest., 43, 2377.

WARD, M. E. AND WatT, P. J. 1975. Studies on the cell biology of gonorrhea. In Genital infections and their complications, edited by D. Danielsson, L. Juhlin and P-A. Mårdh. Almquist and Wiksell International: Stockholm, p. 229. 